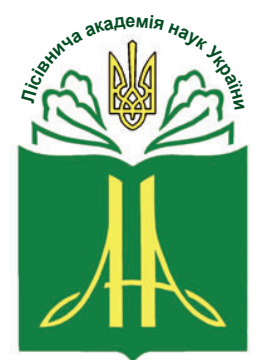

Forestry Academy of Sciences of Ukraine

Наукові праці Лісівничої академії наук України Proceedings of the Forestry Academy of Sciences of Ukraine

http://fasu.nltu.edu.ua

https://doi.org/10.15421/412015

Article received 2020.02.10

Article accepted 2020.06.04
ISSN 1991-606X print

ISSN 2616-5015 online

(a) $\triangle$ Correspondence author Ihor Soloviy

soloviy@yahoo.co.uk

General Chuprynka st., 103, Lviv, 79057, Ukraine

УДК $630 *[477+091]$

\title{
Планування сталого землекористування на основі теорії послуг екосистем: приклад обґрунтування технологічного рішення
}

\author{
І.П. Соловійํ, Р.О. Козак², Т.Я. Кулешник
}

Важливість послуг екосистем для добробуту людини у все більшій мірі визнається у політиці багатьох країн на місцевому, національному та міжнародному рівнях. В Україні ияя концепція все щзе не отримала належної уваги, а тому і не знайшла практичного застосування. Незважаючи на деякі обмеження та методологічні проблеми оцінювання послуг екосистем, інтеграція таких оцінок у процеси прийняття управлінських рішень має стати пріоритетним завданням у сфері менеджменту природних ресурсів, зокрема у сфері планування землекористування. Роль лісового та аграрного секторів особливо важлива у иььоу контексті, оскільки в Украӥні послуги екосистем у лісовому господарстві до уваги не беруться, а термін «послуги агроекосистем» ще навіть не набув поширення у наукових публікаціях, а тим більше на практиці. Оцінювання послуг екосистем необхідно здійснювати на засадах системного підходу шляхом інтеграції екологічних, економічних і соиіокультурних оцінок. Це дасть змогу забезпечити розуміння вигод, отриманих від екосистем, і витрат, пов'язаних з їх використанням. Врахування вартості послуг екосистем внаслідок збереження певних типів рослинності у ландшафті (напр., лісів) та вигід від відмови заподіяння шкоди довкіллю дає змогу розрахувати еколого-економічні вигоди від впровадження нових технологій виробництва. Як приклад у статті розрахована еколого-економічна вигода від впровадження технології виготовлення деревинносолом'яних плит на основі врахування вартості послуг лісових екосистем та вартості екологічних вигод від відмови заподіяння шкоди довкіллю спалюванням соломи і післяжнивних решток.

Ключові слова: вартість послуг екосистем; вигоди; деревинно-солом'яні плити; земельна політика; лісове господарство; сільське господарство.

Вступ. Глобальна система землекористування зазнає безпрецедентного антропогенного навантаження через забруднення довкілля наслідками діяльності базованої на викопних джерелах економіки, небачених темпів змін клімату та зростання кількості населення. Багато сучасних сільськогосподарських практик, методів ведення лісового та водного господарства пригнічують життєво важливі послуги екосистем, тим самим обмежуючи здатність згаданих секторів прогодувати населення, підвищити продуктивність праці, зберегти довкілля та сприяти добробуту людини.

Розуміння наслідків цих впливів $є$ необхідним для розроблення стратегій управління земельни-

Соловій Ігор Павлович - академік Лісівничої академії наук України, віце-президент ЛАН України, доктор економічних наук, професор кафедри екологічної економіки. Національний лісотехнічний університет України, вул. генерала Чупринки, 103, м. Львів, 79057, Україна. Тел.: 032-287-03-88, +38-097-284-08-81. E-mail: soloviy@yahoo.co.uk ORCID: https://orcid.org/0000-0001-5885-6264

2 Козак Руслан Олегович - доктор технічних наук доцент кафедри технологій деревинних композиційних матеріалів, целюлози та паперу. Національний лісотехнічний університет України, вул. генерала Чупринки, 103, м. Львів, 79057, Україна. Тел. +38-0671660177. E-mail: kozak_ruslan@ukr.net ORCID: https://orcid.org/0000-0003-1297-9810

Кулешник Тарас Яркович - здобувач кафедри екологічної економіки. Національний лісотехнічний університет України, вул. генерала Чупринки, 103, м. Львів, 79057, Україна. Тел. +38-067-777-87-47. E-mail: kuleshnyk@gmail.com ORCID: https://orcid.org/0000-00033386-8634 
ми ресурсами, які забезпечуватимуть продовольчу безпеку, ефективне надання послуг екосистем та успішну адаптацію до змін клімату (Holman, Brown, Janes, \& Sandars, 2017). Планування землекористування - це систематична оцінка земельного потенціалу, альтернатив використання землі та економічних і соціальних умов 3 метою вибору і прийняття найкращих варіантів використання земель. Його мета полягає у виборі та здійсненні на практиці тих землекористувань, які найкращим чином задовільнять потреби людей, зберігаючи ресурси для майбутнього. Рушійною силою планування $\epsilon$ потреба у змінах, потреба у поліпшеному управлінні або потреба у зовсім іншій схемі використання земель, зумовленій мінливими обставинами сьогодення. У цьому процесі беруть участь усі види землекористування: сільське господарство, лісове господарство, охорона природи, міські та промислові об'єкти, туризм і рекреація. Планування також дає вказівки у випадку конфліктів між різноманітними альтернативами, вказуючи, які райони є найціннішими для конкретного використання земель. Загалом планування землекористування, з метою забезпечення сталого розвитку, повинно перерости у міждисциплінарний цілісний підхід, який приділяє увагу всім функціям землі та активно залучає всіх землекористувачів і стейкхолдерів шляхом участі в процесі переговорної платформи чи то на національному, чи на місцевому рівнях. Метою цього процесу є створення умов для досягнення екологічно безпечної, соціально бажаної та економічно доцільної форми землекористування.

Відповідно сучасні погляди на політику землекористування трактують іï як засіб досягнення тривалої гармонізації економічних, соціальних та екологічних інтересів у суспільстві на регіональному та місцевому рівнях. Однак такі спроби на практиці можуть потрапити під загрозу провалу через посилення конфліктів інтересів щодо землекористування між різними секторами. Суспільства часто отримують економічну вигоду від екологічних функцій і процесів, таких як енергетичні потоки, кругообіг поживних речовин та гідрологічні процеси (Ring, 2008), пов'язаних 3 наданням необхідних людині послуг екосистем (Haygarth \& Ritz, 2009). Однак звична економічна діяльність враховує лише ті з отриманих від екосистем послуги і товари, які обмінюються на гроші на ринку (наприклад, їжа, вода, деревина), але зазвичай ігнорує ширше коло нематеріальних послуг, які не охоплені ринковими трансакціями (наприклад, захист грунтів від ерозіі, регулювання клімату, забезпечення середовища проживання), навіть у випадках, коли їхні втрати стають незворотними. За оцінками експертів, щорічні втрати від виснажливого використання природних ресурсів і забруднення довкілля в Україні становлять від 15 до 20\% ii національного доходу, i нарощування обсягів виробництва за чинних підходів веде до екологічної катастрофи (Rudneva, 2013). Як доводить Veklych (2019), оцінювання економічного збитку від погіршення/знищення екосистем- них послуг і запровадження отриманих результатів у практику управління, попри надзвичайну актуальність і важливість такого завдання, має безліч невирішених питань у частині наукового, методичного, нормативного, законодавчого та інформаційного характеру.

Водночас через усе більший суспільний тиск, який чинить громадська думка на державні структури та бізнес у всьому світі, спроби надання економічної оцінки активам екосистем посилюються, і політичні структури все більшою мірою змушені їх включати до ініціатив у сфері планування землекористування (Viglizzo, Paruelo, Laterra, \& Jobbagy, 2012). Зважаючи на те, що концепції екологізації економіки та переходу до сталого розвитку все більшою мірою поширюють свою політичну впливовість, політики, землекористувачі, зацікавлені сторони та вчені змушені визнати, що послуги екосистем, ймовірно, будуть у центрі майбутньої політики щодо використання земель.

Той факт, що сьогодні методології оцінювання і моніторингу послуг екосистем ще недостатньо опрацьовані і мають недоліки, не є вагомим аргументом для відмови від їхньої апробації і впровадження у політику землекористування (Viglizzo, Paruelo, Laterra, \& Jobbagy, 2012). Наукове обгрунтування підходів, які здатні забезпечити інтеграцію результатів оцінювання послуг екосистем у процеси формування політики, стратегій розвитку та обгрунтування управлінських рішень $є$ однією із найактуальніщих наукових проблем забезпечення переходу до екологічної економіки і сталого розвитку.

Методика та результати дослідження. Об ' $\mathrm{\epsilon km}$ досліджень - послуги екосистем, пов'язані з функціонуванням системи землекористування. Предмет досліджень - прийняття рішень у сфері землекористування 3 урахуванням вартості послуг екосистем.

Мета роботи полягає у розробленні теоретичних положень і прикладних рішень щодо трансформації системи планування землекористування на засадах сталого розвитку на основі теорії послуг екосистем.

У розглянутому нижче прикладі діяльність промислового підприємства тісно пов'язана з використанням земель, які, з одного боку, є ресурсною базою виробника, а 3 іншого - поглиначем забруднень, що виникають у результаті перетворення вхідних потоків у кінцевий продукт. Виготовлення деревинно-солом' яних плит на заводах стружкових плит супроводжуватиметься не лише вигодами підприємства від застосування додаткового виду сировини - соломи, що має економічний інтерес, але й позитивним екологічним аспектом - перетворенням соломи 3 відходів у технічну сировину, що сприятиме збереженню довкілля та ефективності послуг лісових екосистем.

Наприклад, екологічні вигоди для суспільства від запровадження виробництва деревинно-солом'яних плит можуть бути представлені економічною вигодою від послуг лісової та агро- екосистем 3 погли- 
нання $\mathrm{CO}_{2}$ унаслідок відмови від спалювання соломи та вирубування лісу, як еквівалент зменшення обсягів використання деревинної сировини в процесі виготовлення деревинно-солом'яних плит:

$$
E B=E B_{\text {a.e.c. }}+E B_{\text {л.е.с. }}
$$

де $E B$ - екологічна вигода від послуг екосистем, грн;

$E B_{\text {a.e.c. }}$ - екологічна вигода від збереження агроекосистеми, грн;

$E B_{\text {л.е.с. }}$ - екологічна вигода від збереження лісової екосистеми, грн.

Щорічно після збирання зернових культур у багатьох українських агропідприємствах солому спалюють, посилаючись на те, що заорювання стерні та соломи - технологічно складний агрозахід $\mathrm{i}$, більше того, витратний. Відмову від підпалювання стерні та соломи внесено до низки рекомендацій і систем землеробства, які розробляють на обласному рівні, оскільки такий агрозахід завдає значної шкоди довкіллю та всій агроекосистемі (Demidov et al., 2012).

Зокрема за даними Zhovnir (2012), спалювання біомаси зумовлює викиди, у складі яких зосереджено 32\% оксиду вуглецю, 20\% твердих частинок, $50 \%$ канцерогенних поліароматичних вуглеводнів у світі. Димові гази від спалювання біомаси є надзвичайно небезпечними для здоров'я людини, оскільки значна частка твердих частинок мають розмір менше 10 мкм і легко проникають у дихальні шляхи, спричиняючи різноманітні захворювання. Спалювання соломи спричиняє згоряння напіврозкладених органічних решток, перетворюючи їх на попіл. Під час спалювання соломи вигорає гумус, особливо коли солома лежить у валках або стогах. Відбувається незворотна втрата органічних вуглецю і азоту. Окрім того таке спалювання призводить до загибелі корисних мікроорганізмів, мезофауни, особливо дощових черв'яків та інших мешканців грунту, які відіграють важливу роль в утворенні органічної речовини, у формуванні структури грунту. Гинуть також корисні комахи і птахи (Demidov, Datsko, Panasenko, Bulygin, \& Tymchenko, 2012). Наслідком такого процесу $є$ зниження потенційної родючості грунту i, відповідно, втрата послуг агроекосистеми. Поряд 3 цим, спалювання соломи становить потенційну небезпеку з погляду виникнення пожежі на сусідніх полях, у лісосмугах, лісах, степах i, навіть може становити загрозу для людського життя.

За розрахунками фахівців, розмір повної еколого-господарської шкоди від спалювання соломи і післяжнивних решток на площі поля в 100 га може сягати 830 тис. грн (Demidov et al., 2012).

У цьому випадку екологічна вигода від відмови спалювання соломи може бути розрахована таким чином:

$$
E B_{\text {a.e.c. }}=S_{\text {n.з. }} \cdot B E \Pi_{\text {сп.сол. }}
$$

де $S_{n \text {.з. }}$ - площа посівів зернових, солому яких використовують для виготовлення деревинносолом’яних плит, га;
$B E \Pi_{\text {сn.сол. }}$ - вартість послуг агроекосистеми від відмови спалювання соломи, яка чисельно рівна еколого-господарській шкоді від спалювання соломи і післяжнивних решток, грн/га.

Механізм надання лісом послуг екосистеми полягає у взаємодії лісу з атмосферою, водою, грунтом та у підтриманні їхніх якісних і кількісних параметрів на екологічно оптимальному рівні. До послуг лісових екосистем відносять рекреаційну (оздоровчу) цінність лісових масивів, захист грунтів від ерозії, підвищення урожайності сільськогосподарських культур, збереження біорізноманіття, регулювання водяного стоку, продукування кисню, поглинання двоокису вуглецю та ін.

На особливу увагу заслуговують гідрологічні послуги лісових екосистем (водоохоронні та водорегулятивні), послуги зі збереження біорізноманіття та послуги, пов'язані з поглинанням двоокису вуглецю. Ці послуги можуть знижуватися або бути втраченими (у випадку зрубування чи деградації лісів), що призведе до екологічних небезпек і додаткових витрат для суспільства на місцевому рівні (напр., зумовить повені і зсуви, пришвидшить кліматичні зміни на глобальному рівні тощо) (Soloviy, 2016).

Вигоди від збереження лісової екосистеми можуть бути обчислені через вартість іï послуг та площу лісу, збережену внаслідок виготовлення деревинно-солом'яних плит:

$$
E B_{\text {зб.дер. }}=S_{\text {зб.дер. }} \cdot B E \Pi_{\text {ліс.ек.с. }} \cdot K_{\text {грн }}
$$

де $B E \Pi_{\text {ліс.ек.с. }}$ - річна вартість екологічних послуг лісової екосистеми, \$/га/рік;

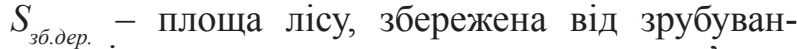
ня внаслідок виготовлення деревинно-солом'яних плит, га;

$K_{\text {грн }}-$ курс гривні стосовно долара, грн/дол.

Економічна вартість послуг лісової екосистеми становить в середньому 1127 \$/га в рік для лісів помірної зони (Costanza et al., 2014), до яких належать і ліси України.

Обсяги виготовлення стружкових плит в Україні за останні роки становлять 1,3-1,6 млн м³/рік (State Statistics Service of Ukraine, 2019). Для виготовлення таких обсягів плит за питомої витрати сировини $1,4-1,5 \mathrm{~m}^{3} / \mathrm{M}^{3}$ заводи використовують $1,9-2,4$ млн м ${ }^{3}$ деревинної сировини (Otlev, 1989). Виготовлення деревинно-солом'яних плит з вмістом соломи 40\% щорічно дасть змогу вивільняти 0,76-0,96 млн м ${ }^{3}$ деревини і залучати 0,32-0,44 млн т соломи. За середнього збору соломи 4,2 т/га (Tarariko, 2005; Klyus, 2012) площа посівів зернових, солома яких використовуватиметься для виготовлення деревинносолом'яних плит, становить 76,2-104,8 тис. га.

Збережену в процесі виготовлення деревинносолом'яних плит від вирубування площу лісів можна визначити з середніх запасів деревостанів України та вивільненого через застосування соломи обсягу деревини. Згідно 3 даними звіту Державного агентства лісових ресурсів України, середні запа- 
си деревостанів України становлять 218 м³/га (Тhe Public Report..., 2016). Тоді збережена від зрубування площа лісу становитиме 3,5-4,4 тис. га. Підставивши дані у формули (1)-(3) отримаємо:

- екологічна вигода від збереження лісової екосистеми:

$$
E B_{\text {зб.дер. }}=(3,5 \ldots 4,4) \cdot 10^{3} \cdot 1127,0 \cdot 26,7^{*}=
$$$$
(105,3 \ldots 132,4) \text {, млн грн; }
$$

* - курс USD за даними НБУ станом на травень 2020 року

- екологічна вигода від збереження агроекосистеми:

$$
\begin{gathered}
E B_{\text {sid...n. }}=(76,2 \ldots 104,8) \cdot 10^{3} \cdot 8,3=(632,5 \ldots 869,8), \\
\text { млн грн; }
\end{gathered}
$$

- екологічні вигоди від послуг екосистем:

$$
\begin{aligned}
E B= & (105,3 \ldots 132,4)+(632,5 \ldots 869,8)= \\
& =(737,8 \ldots 1002,2), \text { млн грн. }
\end{aligned}
$$

На основі еколого-економічної оцінки виробництва деревинно-солом'яних плит розроблено схему еколого-економічних вигод від впровадження технології їх виготовлення (рис.), яка містить три блоки, що відображають причинно-наслідкові зв'язки між послугами екосистем, їх використанням i еколого-економічними наслідками.

Схема ілюструє вартісну оцінку сучасного стану екологічних збитків від спалювання соломи i використання деревини для виготовлення стружкових плит, а також вартісний еквівалент екологічних вигод від впровадження технології деревинносолом'яних плит, який становить 737,8...1002,2 млн грн.

Дискусія. Проаналізований приклад добре ілюструє доречність застосування концепції послуг екосистем для обгрунтування політики сталого землекористування та прийняття технологічних рішень. Ми свідомі стосовно певних обмежень наведеного розрахунку, який не містить усіх етапів еколого-економічного обгрунтування, адже до уваги не брали виробничі витрати, фактор часу тощо. Але ми мали за мету зосередити увагу саме на послугах екосистем лісоаграрного ландшафту, які на сьогодні не беруться до уваги як у сільському, так і в лісовому господарстві України.

Екосистемні послуги сприяють створенню доходів і добробуту, а також запобіганню збитків, які завдають суспільству вагомих втрат. Усі види вигод, а також і витрат, пов'язаних із використанням екосистемних послуг, повинні так чи інакше враховуватися у процесах прийняття рішень. Оцінювання послуг екосистем допомагає визначити бенефіціарів та отримати дані щодо обсягів можливих виплат. Це допоможе отримати інформацію про належний рівень платежів за послуги екосистеми і визначити, чи варто їх застосовувати (Nijnik, 2020).

Досвід показує, що використання щодо екосистем та їхніх послуг таких означень як «незамінні», «безцінні» або ж «нематеріальні» блага виявилось для суспільства недостатнім 3 погляду припинення деградації екосистем. Розробники політики, різні землекористувачі та зацікавлені сторони повинні усвідомити, що послуги екосистем стають дедалі дефіцитнішими і що не вдасться керувати тим, що не має ціни (Viglizzo et al., 2012).

Щоб вирішувати актуальні проблеми сьогодення, дослідження повинні ставати проблемно-, а не інструментально-орієнтованими (Hahn, 2000). Постає питання, а до якої міри науковці готові стати вирішувачами проблем, а не лише технічними фахівцями - виконавцями поставлених завдань?

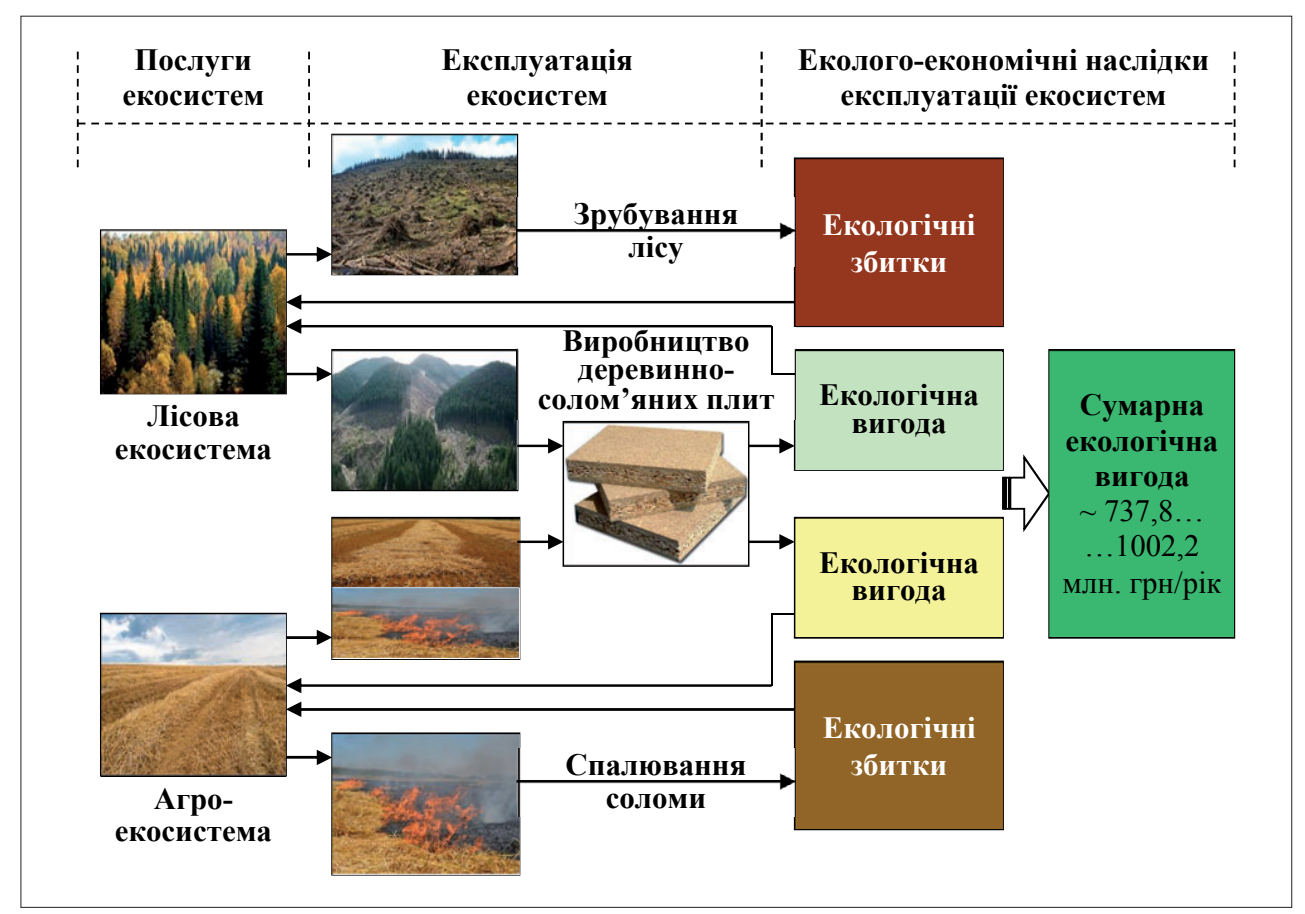

Рис. Еколого-економічні вигоди від впровадження технології виготовлення деревинно-солом’яних плит 
Висновки. Незалежно від відповіді на поставлене вище запитання, науковці змушені аналізувати, чому і яким чином численні інтереси різних зацікавлених сторін і секторів у суспільстві можуть впливати на застосування методів і прийомів у політиці як щодо землекористування, так і стосовно менеджменту природних ресурсів та використовуваних технологій назагал.

Розрахована еколого-економічна вигода від впровадження технології виготовлення деревинносолом'яних плит на основі врахування вартості послуг лісових екосистем та вартості екологічних вигод від відмови заподіяння шкоди спалюванням соломи і післяжнивних решток, становить близько мільярда гривен на рік. Однак сьогодні послуги екосистем не беруться до уваги повною мірою в лісовому господарстві України, традиційно йдеться лише про функції лісів. У сільському господарстві термін «послуги агроекосистем» ще не знайшов використання навіть у наукових публікаціях, не кажучи вже про законодавчо-нормативну базу та практику обгрунтування господарських рішень.

Яким же чином досягти таких суттєвих змін у підходах до формування секторальної політики, щоб результати оцінювання послуг екосистем стали корисними, обов'язковими для формування політики сталого землекористування, прийняття рішень у сільському і лісовому господарстві? Цей виклик вимагає від дослідників значно більших зусиль, ніж висування гарних ідей та геніальних методів оцінювання, які, на жаль, не впливають вирішально на громадську думку та дії політиків.

У той же час потрібно визнати, що попит на послуги екосистем швидко зростатиме в міру збільшення населення та рівня життя у світовому вимірі. Тому необхідно чітко констатувати, що оцінка послуг екосистем - це інструмент для творення оптимальних сценаріїв землекористування на засадах сталого розвитку.

\section{References}

Baranchuk, V.M. (2006). Outcomes of the work of the Ministry for Industrial Policy for 2005. World of Furniture and Wood, 1, 6-11 (in Ukrainian).

Costanza, R., R. de Groot, Sutton, P. S., van der Ploeg, S., Anderson, I., Kubiszewski, S., \& Farber, R. K. (2014). Changes in the global value of ecosystem services. Global Environ. Chang, 26, 152-158. https://doi. org/10.1016/j.gloenvcha.2014.04.002

Hahn, R.W. (2000). The impact of economics on environmental policy. Journal of Environmental Economics and Management, 39, 375-399. https:// doi.org/10.1006/jeem.1999.1119

Haygarth, P.M., \& Ritz, K. (2009). The future of soils and land use in the UK: soil systems for the provision of land-based ecosystem services. Land Use Policy, 26, 187-197. https://doi.org/10.1016/j. landusepol.2009.09.016

Holman, I. P., Brown, C., Janes, V., Sandars, D. (2017). Can we be certain about future land use change in
Europe? A multi-scenario, integrated-assessment analysis. Agricultural Systems, 151, 126-135. https:// doi.org/10.1016/j.agsy.2016.12.001

IUCN (2015) Forest Landscape Restoration. Retrieved September 25, 2016. Retrieved from https://www. iucn.org/theme/forests/our-work/forest-landscaperestoration

Klyus, S. V. (2012). Determination of energy potential of straw and plant waste during the period of independence of Ukraine. Renewable Energy, 3, 71-79. Retrieved from http://nbuv.gov.ua/UJRN/ vien_2012_3_14 (in Ukrainian).

MEA (2005). Ecosystems and Human Well-being: Multiscale Assessment, Millennium Ecosystem Assessment Series, 4. Washington, DC: Island Press.

Medvedev, Y.S. (2003). Results of the furniture and woodworking industry. Prospects for the development of the board industry. The world of furniture and wood, 1, 3 (in Ukrainian).

Demidov O.A., Datsko L.V., Panasenko V.M., Bulygin S. Yu., \& Tymchenko D. O. (2012). Methods of calculating losses from burning stubble and straw. Scientific and Practical Yearbook «Manual of Ukrainian farmers», 16, 25-28. Retrieved from: https://fermer.ru/files/forum/2013/09/1758 67/izvlech_stranicy_izposobie_hleboroba.pdf (in Ukrainian).

Nijnik, M. (2020). Valuation of ecosystem services: a panacea or Pandora's box for decision-makers? In Workshop Proceedings Development of scientific and methodical bases for ecosystem services valuation in Ukraine, 49-50. Lviv, Ukraine: Ukrainian National Forestry University.

Otlev, I.A. (1989). Intensification of chipboard production. Moscow: Forest industry (in Russian).

Ring, I. (2008). Integrating local ecological services into intergovernmental fiscal transfers: the case of the ecological ICMS in Brazil. Land Use Policy, 25, 485-497. https://doi.org/10.1016/j. landusepol.2007.11.001

Rozora, I.F., \& Saganyuk, M.P. (2004). Results of the work for 2003 and development prospects of the furniture and woodworking industry of Ukraine. World of furniture and wood, 1, 6-7 (in Ukrainian).

Rudneva, O.Y. (2013). Development of tools of environmental and economic management of industrial production. Business Inform, 6, 308-312. Retrieved from http://nbuv.gov.ua/UJRN/binf_2013 6_54 (in Ukrainian).

Sagal, S.Z. (2014). Analysis of the potential of the forest sector of Ukraine and identification of factors that inhibit its innovative development. Woodworking segment. Retrieved from http://www.fleg.org.ua (in Ukrainian).

Saganyuk, M.P. (2005). Results of the work of enterprises of woodworking and furniture industry of Ukraine for 2004. World of furniture and wood, 1, 5-6 (in Ukrainian).

Soloviy, I.P. (2016). Evaluation of ecosystem services provided by forests of Ukraine and proposals for 
mechanisms of payment for ecosystem services. Kyiv: FLEG II. Retrieved from http://www.enpi-fleg. org/docs/evaluation-of-forest-ecosystem-servicesprovided-by-forests-of-ukraine-and-proposals-onpes-mechanisms/ (in Ukrainian).

State Statistics Service of Ukraine (2019). Official site [Electronic resource]. Retrieved from www.ukrstat. gov.ua (in Ukrainian).

Tarariko, Y.O. (2005). Formation of sustainable agroecosystems: Theory and practice. Kyiv: Agrarian science (in Ukrainian).

The Public Report of the Head of the State Agency of Forest Resources of Ukraine for 2016 [Electronic resource]. State Agency of Forest Resources of Ukraine. Retrieved from http://dklg.kmu.gov.ua (in Ukrainian).

United Nations (2016). Forest action statements and action plans. September 25, 2016. Retrieved from http://www.rff.org.

Varenytsia, V.O. (2001). Results of work of furniture and woodworking industry. The State Committee on Industrial Policy of Ukraine for 2000. World of Furniture and Wood, 1, 5-12 (in Ukrainian).

Veklych, O. O. (2019). Parameterization of economic damage from deterioration / destruction of ecosystem services. Economics of nature management and sustainable development, 5, 58-64. Retrieved from http://nbuv.gov.ua/UJRN/epod_2019_5_12 (in Ukrainian).

Viglizzo, E.F., Paruelo, J.M., Laterra, P., \& Jobbagy, E.G. (2012). Ecosystem service evaluation to support land-use policy. Agriculture, Ecosystems and Environment, 154, 78-84. Retrieved from http:// bestp.agro.uba.ar/wp-content/uploads/2014/02/ Vigilizzo_2012_Ecosystem-service-evaluation-tosupport-land-use-policy.pdf

Zhovnir, N.M. (2012). Analysis of the normative requirements for the pollutants emission during the biomass combustion. Industrial Heat Engineering, 1, 77-86. Retrieved from http://dspace.nbuv.gov.ua/ bitstream/handle/123456789/59058/10-Zhovmir. pdf? sequence $=1$ (in Ukrainian).

\section{Планирование устойчивого землепользования на основании теории экосистемных услуг: пример обоснования технологического решения}

\author{
И.П. Соловий ${ }^{1}$ Р.О. Козак², Т.Я. Кулешнык ${ }^{3}$
}

Важность услуг экосистем для благосостояния человека во все большей степени признается в политике многих стран на местном, национальном и международном уровнях. В Украине эта концепция все еще не получила должного внимания, поэтому и не нашла практического применения. Вследствие все большего общественного давления, которое оказывает обще- ственное мнение на государственные структуры и бизнес во всем мире, возрастают попытки осуществления экономической оценки активов экосистем, а политические структуры во все большей степени вынуждены включать их в инициативы в области планирования землепользования. Несмотря на то, что концепции экологизации экономики и перехода к устойчивому развитию во все большей степени усиливают свое влияние на политиков, землепользователи, различные незаинтересованные стороны, в частности ученые, вынуждены признать, что услуги экосистем, вероятно, будут в центре будущей политики по использованию земель.

Несмотря на некоторые ограничения и методологические проблемы оценки услуг экосистем, интеграция таких оценок в процессы принятия управленческих решений должна стать приоритетной задачей в сфере менеджмента природных ресурсов, в частности в области планирования землепользования. Роль лесного и аграрного секторов особенно важна в этом контексте, поскольку в Украине услуги экосистем не принимаются во внимание в лесном хозяйстве, а термин «услуги агроэкосистем» не употребляется ни в научных публикациях, ни тем более на практике. Оценки услуг экосистем необходимо проводить на основании системного подхода путем интеграции экологических, экономических и социокультурных оценок. Это позволит обеспечить понимание выгод, полученных от экосистем, и расходов, связанных с их использованием. Учет стоимости услуг экосистем в результате сохранения определенных типов растительности в ландшафте (напр., лесов) и выгод от отказа причинения вреда окружающей среде позволяет рассчитать эколого-экономические выгоды от внедрения новых технологий производства. В качестве примера в статье рассчитана эколого-экономическая выгода от внедрения технологии изготовления древесно-соломенных плит на основании учета стоимости услуг лесных экосистем и стоимости экологических выгод от отказа причинения вреда окружающей среде сжиганием соломы и остатков сбора урожая. Рассчитанная экологоэкономическая выгода от внедрения технологии из-

\footnotetext{
Соловий Игорь Павлович - академик Лесной академии наук Украины, вице-президент ЛАН Украины, доктор экономических наук, профессор кафедры экологической экономики. Национальный лесотехнический университет Украины, ул. генерала Чупринки, 103, г. Львов, 79057, Украина. Тел.: 032-287-03-88, +38-097-284-08-81. E-mail: soloviy@ yahoo.co.uk ORCID: https://orcid.org/0000-0001-5885-6264.

Козак Руслан Олегович - доктор технических наук, доцент кафедры технологий древесных композиционных материалов, целлюлозы и бумаги. Национальный лесотехнический университет Украины, ул. генерала Чупринки, 103, г. Львов, 79057, Украина. Тел .: 032-238-44-99. E-mail: kozak_ruslan@ ukr.net ORCID: https://orcid.org/0000-0003-1297-9810

Кулешник Тарас Яркович - соискатель кафедры экологической экономики. Национальный лесотехнический университет Украины, ул. генерала Чупринки, 103, Львов, 79057, Украина. E-mail: kuleshnyk@gmail.com ORCID: https://orcid.org/00000003-3386-8634
} 
готовления древесно-соломенных плит на основании учета стоимости услуг лесных экосистем и стоимости экологических выгод от отказа причинения вреда сжиганием соломы и послеуборочных остатков, составляет миллиард гривен в год.

Разработчики политики, различные землепользователи и заинтересованные стороны должны осознать, что услуги экосистем становятся все более дефицитными, и должны быть оценены, так как не удастся эффективно управлять тем, что не имеет цены. В то же время спрос на услуги экосистем будет быстро возрастать по мере увеличения численности населения и уровня жизни. Поэтому оценка услуг экосистем - это незаменимый инструмент для создания оптимальных сценариев землепользования на принципах устойчивого развития.

Ключевые слова: стоимость услуг экосистем; выгоды; древесно-соломенные плиты; земельная политика; лесное хозяйство; сельское хозяйство.

\section{Sustainable Land Use Planning on the Basis of Ecosystem Services Theory: the Case with Technology Decision Substantiation}

\section{Soloviy ${ }^{1}$, R. Kozak², T. Kuleshnyk ${ }^{3}$}

The importance of ecosystem services for human well-being is increasingly recognized in the policies of many countries at the local, national and international levels. In Ukraine, this concept has not yet received due attention, and therefore has not found practical application.

Many modern agricultural, forestry and water management practices suppress vital ecosystem services, thereby limiting the ability of these sectors to feed the population, increase work productivity, preserve the environment and promote human wellbeing. Understanding the mature of these impacts is essential for developing land management strategies that will ensure food security, broad array of ecosystem services and successful adaptation to climate change.

As the concepts of greening the economy and transitioning to sustainable development increasingly

Ihor Soloviy - full Member of the Forestry Academy of Sciences of Ukraine, Vice-president of the Ukrainian Forestry Academy of Sciences, Doctor of Economic Sciences, Professor of the Department of Ecological Economics. Ukrainian National Forestry University, 103 General Chuprynka st., Lviv, 79057, Ukraine. Tel.: 032-287-03-88, + 38-097-284-08-81. E-mail: soloviy@yahoo. co.uk ORCID: https://orcid.org/0000-0001-5885-6264.

Ruslan Kozak - Doctor of Technical Sciences, Associate Professor, Department of Wood-Based Composites, Cellulose and Paper. Ukrainian National Forestry University, 103 General Chuprynka st., Lviv, 79057, Ukraine. Tel.: 032-238-44-99. E-mail: kozak_ruslan@ukr.net ORCID: https://orcid.org/0000-0003-1297-9810_

Taras Kuleshnyk - PhD, the Department of Ecological Economics. Ukrainian National Forestry University, 103 General Chuprynka st., Lviv, 79057, Ukraine. Tel. + 38-067-777-87-47. E-mail: kuleshnyk@gmail.com ORCID: https://orcid.org/0000-0003-3386-8634 extend their influence to global politicians, land users, stakeholders and scientific community they all are forced to recognize that ecosystem services are likely to be at the heart of future sustainable land use policy.

Despite some limitations and methodological problems in the evaluation of ecosystem services, the integration of such assessments into management decision-making processes should become a priority in the field of natural resource management, in particular in the field of land use planning. The role of the forest and agricultural sectors is particularly important in this context, as ecosystem services are not taken into account in forestry in Ukraine, and the term «agroecosystem services» has not become widespread in scientific publications or even not mentioned in practice. Evaluation of ecosystem services should be carried out on the basis of a systems approach by integrating environmental, economic and socio-cultural assessments. This will provide an understanding of the benefits derived from ecosystems and the costs associated with their use. Taking into account the cost of ecosystem services due to the preservation of certain types of vegetation in the landscape (eg forests) and the benefits of avoiding environmental damage makes it possible to uncover the environmental and economic benefits of the introduction of new production technologies. As a case study, we calculated the environmental and economic benefits of implementing technology for the production of wood-straw boards based on the cost of forest ecosystem services and the cost of environmental benefits from the refusal to harm the burning of straw and post-harvest residues.

Ecosystem services help generate income and well-being in broad sense and prevent loosing costs to society. All kinds of benefits (and costs) must be taken into account in one way or another in decisionmaking processes. Evaluation of ecosystem services helps to identify beneficiaries and obtain data on the recommended scale of possible payments for ecosystem services (PES). This helps to obtain information on the appropriate level of PES and to determine whether they should be applied or not in concrete case.

How to achieve such significant progress in the approaches to the sectoral policies formation, so that the results of ecosystem services evaluation became useful tool and mandatory requirement for the formation of sustainable land use policy, decisionmaking in agriculture and forestry? This challenge requires researchers to work harder for influencing on public opinion and politicians vision. To address current real-world problems studies must become much more problem-oriented rather than instrumental-oriented. Therefore researchers will have to analyze the interests of different stakeholders and sectors and politicians in society and in which way they can influence the application of their methods and techniques in policy to both land use planning and natural resource management in general planning.

Key words: ecosystem services value; benefits; wood-straw boards; land policy; forestry; agriculture. 